University of Rhode Island

DigitalCommons@URI

The Rhode Island Current Conditions Index

Economics

9-2005

\title{
Rhode Island Current Conditions Index - September 2005
}

Leonard Lardaro

University of Rhode Island, lardaro@uri.edu

Follow this and additional works at: https://digitalcommons.uri.edu/ricci

Part of the Econometrics Commons

Terms of Use

All rights reserved under copyright.

\section{Recommended Citation}

Lardaro, Leonard, "Rhode Island Current Conditions Index -- September 2005" (2005). The Rhode Island Current Conditions Index. Paper 97.

https://digitalcommons.uri.edu/ricci/97

This Article is brought to you for free and open access by the Economics at DigitalCommons@URI. It has been accepted for inclusion in The Rhode Island Current Conditions Index by an authorized administrator of DigitalCommons@URI.For more information, please contact digitalcommons-group@uri.edu. 


\section{BURRENT D}

EONITIONS

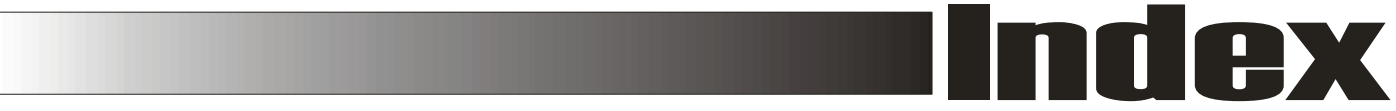

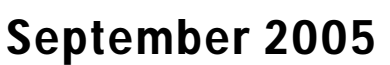

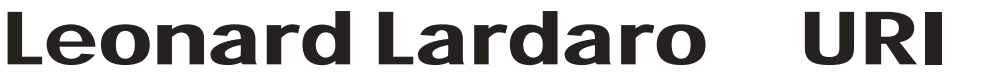

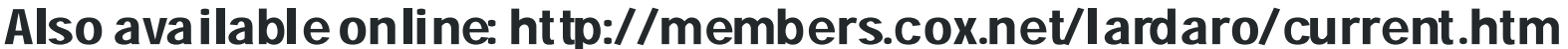

The third quarter ended on a disappointing note, as the Current Conditions Index remained where it has been all quarter, at 58, with seven indicators improving. While Rhode Island's economy continues to grow, it does so without a great deal of momentum.

There was some good news to be found in September, most notably in continued strong performances by our Labor Force, Benefit Exhaustions, and New Claims. And, even though payroll employment now has fallen on a month-to-month basis for two consecutive months, neither change has been statistically significant. More importantly, resident employment, which measures the numbers of Rhode Islanders who are working, jumped by a strong 2.4 percent in

\begin{tabular}{lr}
\multicolumn{2}{c}{ CCI I ndicators - \% Change } \\
Government Employment & -0.6 \\
US Consumer Sentiment & -18.2 \\
Single-Unit Permits & -4.2 \\
Retail Sales & $1.9 \mathbf{Y}$ \\
Help Wanted Advertising & $0.7 \mathbf{Y}$ \\
Priv. Serv-Prod Employment & $2.3 \mathbf{Y}$ \\
Man-Hours Manufacturing & -4.6 \\
Manufacturing Wage & $1.7 \mathbf{Y}$ \\
Labor Force & $3.1 \mathbf{Y}$ \\
Benefit Exhaustions & $-15.7 \mathbf{Y}$ \\
New Claims & $-6.9 \mathbf{Y}$ \\
Unemployment Rate & 12.0 \\
\multicolumn{1}{c}{ Y = I mproved Value } &
\end{tabular}

September versus one year ago and by 2,500 compared to one month ago. As with the nation, the question of which labor market survey (household or establishment) is more relevant for tracking employment should be the subject of debate here.

Retail Sales, which has been one of our strongest indicators for quite a while, rose in September by 1.9 percent, following a double-digit gain in August. This occurred in spite of yet another drop in US Consumer Sentiment, 18.2 percent, its ninth in the last year, the result of rapidly rising gasoline and energy costs. The growth in labor demand, in terms of Help Wanted Advertising, remained slow in September, $(+0.7 \%)$, while layoffs, as measured by New Claims, declined by 6.9 percent and long-term unemployment, measured by Benefit Exhaustions, fell by at a double-digit rate $(15.7 \%)$. September marked the fourth consecutive month for which both New Claims and Benefit Exhaustions improved, and only the seventh time that both have simultaneously improved over the past twelve months. The slowdown in labor demand growth may be signaling the end of this trend by year's end.

September saw another dramatic rise in our Labor Force $(+3.1 \%)$, an increase of 17,400 over its value last September. Our Labor Force has now risen every month since March, reversing last year's string of persistent declines. In view of the recent rapid increases in our Labor Force, the September spike in our Unemployment Rate, from 5 to 5.6 percent, indicates less of a problem than were the Labor Force still declining as it was last year.

Government Employment declined slightly in September (by $0.6 \%$ ), falling below 66,000 . As this was occurring, the growth in Private Service-Producing Employment managed to sustain its recent high of 2.3 percent for the third consecutive month, once again matching its highest rate in the past year.

Economic weakness in September was concentrated in our goods-producing sector. Manufacturing Man-hours slid by 4.6 percent compared to last September, which was among its most rapid rates of decline in the past year. And, while Manufacturing Wage growth improved to 1.7 percent in September, its level remains at only $\$ 13.21$ on a seasonally adjusted basis, far below the national average. Finally, new home construction, as measured by Single-Unit Permits, fell at a slower rate in September (by $4.2 \%$ ) than August, marking its eleventh decline in the past year.

As we move into the fourth quarter, energy prices, rising interest rates, and slowing housing momentum take center stage. Rhode Island's economy appears to be stuck in "low" gear. Hopefully our economic engine will not ultimately stall as the pace of the national economy slows.

\section{Ca Over the Past 13 Months}

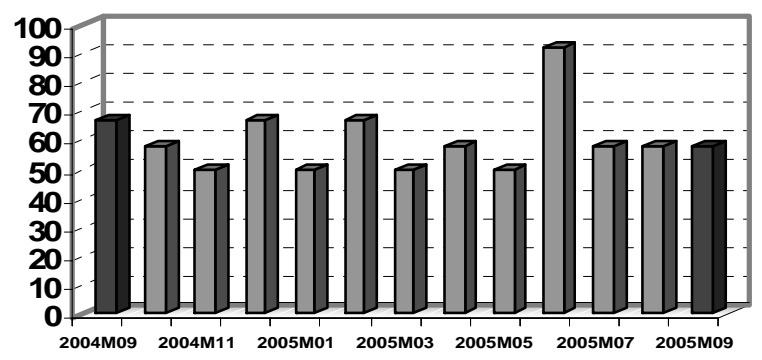

\begin{tabular}{|c|c|c|c|c|c|c|c|c|c|c|c|c|}
\hline & Jan & Feb & Mar & Apr & May & $J$ un & Jul & Aug & Sep & Oct & Nov & Dec \\
\hline 2004 & 67 & 67 & 58 & 67 & 58 & 58 & 67 & 67 & 67 & 58 & 50 & 67 \\
\hline 2005 & 50 & 67 & 58 & 58 & 50 & 92 & 58 & 58 & 58 & & & \\
\hline
\end{tabular}

